\title{
Effect of Weather Parameters on Infestation of Blast Disease (Pyricularia oryzae) in Rabi Season Rice (Oryza sativa L.) in East \& South Eastern Coastal Plain of Odisha
}

\author{
J. Pradhan ${ }^{1 *}$, A. Baliarsingh ${ }^{1}$, G. Biswal ${ }^{2}$, M.P. Das ${ }^{3}$ and S. Pasupalak ${ }^{1}$ \\ ${ }^{1}$ Department of Agricultural Meteorology, College of Agriculture, OUAT, Bhubaneswar, \\ Odisha, India \\ ${ }^{2}$ Department of Plant Pathology, College of Agriculture, OUAT, Bhubaneswar, Odisha, India \\ ${ }^{3}$ Department of Vegetable Science, College of Agriculture, OUAT, Bhubaneswar, \\ Odisha, India \\ *Corresponding author
}

\begin{abstract}
Keywords
Rice, Rice blast disease, Variety, Weather parameters, Pyricularia oryzae

Article Info

Accepted:

10 October 2018

Available Online:

10 November 2018 minimum temperature, rainfall, maximum relative humidity, minimum relative humidity, wind velocity, bright sunshine hours and evaporation) on infestation of $P$. grisea in rice (in the varieties Khandagiri and Lalat). In rabi season among the two varieties, Lalat variety showed the higher blast incidence $(2.17 \%)$ whereas Khandagiri variety showed lowest blast incidence $(1.32 \%)$. The incidence of blast disease in variety Khandagiri was significant and high positively correlated with Minimum Temperature, Wind velocity, Evaporation. The blast disease incidence was positively correlated with Maximum Temperature, Minimum Relative humidity. The incidence of blast disease in variety Lalat was significant and high positively correlated with Minimum Temperature. The blast disease incidence was positively correlated with Maximum Temperature, Wind velocity, Evaporation and negatively correlated with Maximum Relative humidity. Rainfall, Minimum Relative humidity and BSH have no effect on the disease incidence. Weather parameters played a major role in disease incidence in rabi season and in this location, among the two different varieties Lalat variety is very susceptible to blast disease than Khandagiri.
\end{abstract}

\section{A B S T R A C T}

An investigation was carried out at Agrometeorological field, Central Research Farm, Odisha University of Agriculture and Technology, Bhubaneswar in rabi season, 2017 in natural condition on study of various aspects of effect of weather (maximum temperature,

\section{Introduction}

Rice (Oryza sativa L.) is the staple food for more than $60 \%$ of the world's population and more than $90 \%$ of the rice produced in the world is consumed in the Asian countries. Globally during 2011-12, rice crop occupied an area of about 159.22 million hectares with 465.81 million tonnes of production and productivity of 4.36 metric tonnes per hectare (USDA, 2013). The major rice producing countries are China, India, Indonesia, Bangladesh, Vietnam, Thailand, Myanmar, Philippines, Brazil and Japan. 
Rice cultivation is the major activity and source of income for millions of households round the globe. Several countries of Asia and Africa are highly dependent on rice as source of foreign exchange earnings and government revenue. Rice production is geographically concentrated in Western and Eastern Asia and Asia is the biggest rice producer, accounting for $90 \%$ of the world's production. The per capita consumption of rice in Asian countries is 200-400lb (90-181 kg) per person. China and India produce half of the world's rice production (FAO, 1999).

Rice is the staple food of over half the world's population and a vital nutritional source for rural poor of most of the countries in the world providing $20 \%$ of their dietary energy. The demand of rice as staple food for about 3 billion people is expected to increase further with increase in population. In India it occupies an area of 43388 thousand ha producing 104317 thousand tonnes with an average productivity $2404 \mathrm{~kg} / \mathrm{ha}$. In Odisha occupies an area of 3943 thousand ha producing 5878 thousand tonnes with an average productivity of $1491 \mathrm{~kg} / \mathrm{ha}$ (Directorate of Economics \& Statistics, DAC \& FW, 2015-16).

Agro-climatic conditions prevailed in a region are most important factors contributing towards build up diseases. The crop is attacked by number of fungi, bacteria, viruses and nematodes besides non-parasitic disorders. Among them, fungi alone account for more than thirty diseases, of which rice blast caused by Pyricularia oryzae (Magnaporthe grisea) is one of the most prevalent disease found in India which is a major limiting factor in rice productivity of the country and in several parts of the world.

The blast disease was first recorded from Tanjore district of Tamil Nadu in 1918. The blast disease remains a threat to rice production because of its apparently unpredictable outbreaks and the resulting economic losses depending on weather. Rice blast is devastating and the pathogen can cause yield loss ranging from 30-61\% depending upon the stage of infection. In severe cases, losses amounting to $70-80 \%$ in South-East Asia and India. The disease results in yield loss as high as $70-80 \%$ when predisposing factors (high mean temperature, relative humidity higher than $85-89 \%$, presence of dew, drought stress and excessive nitrogen fertilization) favour epidemic development. Subtropical or temperate environment where canopy wetness is frequent along with moderate temperature are inductive to blast.

A systematic study on the effect of weather on infestation of blast disease in rice in Odisha is necessary and information pertaining to screening of rice varieties for this region is yet to be generated. Keeping these points in view, the present investigation was undertaken to generate information on identification of blast resistance varieties in rice in natural condition.

\section{Materials and Methods}

A field experiment was conducted during the rabi season 2017 at Agrometeorological field, Central Research Farm, Odisha University of Agriculture and Technology (OUAT), Bhubaneswar situated at an elevation of 25.9 $\mathrm{m}$ above mean sea level, $20^{\circ} 15^{\prime} \mathrm{N}$ latitude and $85^{\circ} 52^{\prime}$ E longitude. During this time period, the average maximum temperature ranged between $31.9-37^{\circ} \mathrm{c}$, minimum temperature $16.7-26.7^{\circ} \mathrm{c}$, total rainfall 74.6mm, maximum RH 86.3-94.1\%, minimum RH $35.4-55.1 \%$, wind velocity 2.1 $11.1 \mathrm{~km} / \mathrm{hr}$, bright sunshine hours $7.5-8.7 \mathrm{hrs}$, evaporation $3.7-7.8 \mathrm{~mm}$. Rice varieties Khandagiri and Lalat were transplanted with a spacing of $10 \mathrm{~cm} \times 20 \mathrm{~cm}$ with replication two in RBD. 
Ten diseased plants were selected randomly in " $Z$ " pattern from each plots and tagged. The diseased leaves of rice plants collected from farmers' fields were used for the isolation of the pathogen. The pathogen was isolated by following standard tissue isolation procedure (Tuite, 1969). Small bits of diseased leaves along with some healthy tissue were cut with help of a sterile scalpel and surface sterilized with one per cent sodium hypochlorite solution for $1 \mathrm{~min}$. and rinsed aseptically in three changes of sterilized distilled water. Such surface sterilized leaf bits were transferred aseptically into sterilized Petri dishes containing solidified oat meal agar medium and incubated at $28 \pm 1^{0} \mathrm{C}$ for two weeks in a BOD incubator.

Per cent disease index (PDI) was calculated after scoring the per cent disease severity of leaf blast disease, following standard formula given by Mckinney (1923).

$$
\text { PDI }=\frac{\text { Total no. of leaflets observed } \times \text { maximumrating }}{\text { Toll numerical ratings }} \times 100
$$

The data obtained from all the experiments were statistically analyzed by the following standard methods of Panse and Sukhatme (1984) and Gomez and Gomez (1984). The simple correlation and multiple linear regression analysis were done as per the standard methods to work out the relationship between weather factors and disease development by using statistical analysis programme like SAS, Pearson Correlation Coefficient.

\section{Results and Discussion}

In rabi season 2017 the per cent disease index (PDI) and mean weather parameters like maximum temperature, minimum temperature, total rainfall, maximum relative humidity (RH), minimum RH, wind velocity, Bright sunshine hour and evaporation of the two varieties Khandagiri and Lalat were worked out at weekly interval and presented in Table 1 and 4. Two simple correlation matrices were worked out by taking PDI and eight weather variables viz., maximum temperature $\left(\mathrm{X}_{1}\right)$, minimum temperature $\left(\mathrm{X}_{2}\right)$, total rainfall $\left(\mathrm{X}_{3}\right)$, maximum $\mathrm{RH}\left(\mathrm{X}_{4}\right)$ and minimum $\mathrm{RH}\left(\mathrm{X}_{5}\right)$, wind velocity $\left(\mathrm{X}_{6}\right)$, Bright sunshine hour $\left(\mathrm{X}_{7}\right)$ and evaporation $\left(\mathrm{X}_{8}\right)$ in consideration (Table 1 and 4).

During rabi season 2017, the blast disease incidence started $7^{\text {th }}$ standard meteorological week (SMW) (15 Feb, 2017) $0.48 \%$ to a maximum incidence of $1.32 \%$ in $16^{\text {th }}$ standard meteorological week (SMW) (19 Apr, 2017) in variety khandagiri and in variety lalat, incidence occurred in $7^{\text {th }}$ standard meteorological week (SMW) (15 Feb, 2016) to a highest range $2.17 \%$ in $17^{\text {th }}$ standard meteorological week (SMW) (26 Apr, 2017). This supports the findings of Gowda and Gowda (1985) who found that rice crop sown fortnightly in January to June developed not more than $5 \%$ of leaf blast and $1 \%$ neck blast. Chaudhary and Vishwadhar (1988) reported that rice crop sown at the earliest date $\left(15^{\text {th }}\right.$ March) showed the lowest levels of foliage blight caused by P. oryzae (34.6\%).

In both of the varieties (Khandagiri and Lalat), the PDI was gradually increasing with the advancement of dates of observation and the maximum disease severity observed at $16^{\text {th }}$ and $17^{\text {th }}$ SMW, when the maximum temperature $\left(37^{0} \mathrm{c}\right)$, minimum temperature $\left(25.2^{0} \mathrm{c}\right)$, total rainfall $(29.2 \mathrm{~mm})$, maximum $\mathrm{RH}(87.4 \%)$ and minimum RH $(50.3 \%)$, wind velocity $(7.9 \mathrm{~km} / \mathrm{hr}$, Bright sunshine hour (8.7hrs) and evaporation $(7.4 \mathrm{~mm})$ were recorded.

\section{Maximum and minimum temperature}

Rises of temperature cause blast disease $(2.17 \%)$ in rice. Blast disease is directly 
significant to both maximum and minimum temperature. During the blast disease occurrence period the maximum temperature ranged between $31.9-37^{\circ} \mathrm{c}$ and minimum temperature $16.7-26.7^{0} \mathrm{c}$. Both the maximum \& minimum temperature influences the disease severity in both the verities. Similar findings also found by the work of Ramakrishnan (1948), Chakrabarti and Padmanabhan (1968), Kato and Kozaka (1974), Kapoor and Singh (1977), Gouramanis (1994), Shafaullah et al., (2011) and Rajput et al., (2017).

\section{Rainfall}

During this period rainfall was less so the disease severity was less. Pal et.al (2017) found that due to scanty rainfall scanty in 2014 and in general, the disease severity was less as compared to 2013.

\section{Relative humidity}

During this period the maximum and minimum RH ranged between RH 86.3-94.1\% and $35.4-55.1 \%$ respectively. Relative humidity influences the disease incidence. It is as same as the findings of Gouramanis (1994), Castejon-Munoj (2008), Shafaullah et al., (2011) and Syakira et al., (2016).

\section{Wind velocity}

During the growing period wind velocity ranged $2.1-11.1 \mathrm{~km} / \mathrm{hr}$. Wind velocity playes an important role in the blast disease incidence during this period. Studies have been carried out on air mycoflora around Jabalpur by Verma Khare $(1987,1988)$ and in Gulbarga by Bhat and Rajasab (1988). On pathogenic and non-pathogenic mycoflora in the air and phylloplane of Triticum aestivum L. by Uddin and Chakraverty (1996).

\section{Bright sunshine hours}

BSH have no interaction with blast disease incidence because during this growing period the BSH is required for the disease incidence is not as par.

\section{Evaporation}

Evaporation is optimal for the growth and development for the incidence of blast disease.

Table.1 Influence of weather parameters on Blast disease of Khandagiri variety during rabi, 2017

\begin{tabular}{|c|c|c|c|c|c|c|c|c|c|c|}
\hline \multirow[t]{2}{*}{$\begin{array}{c}\text { WEEK } \\
\text { NO. }\end{array}$} & \multirow[t]{2}{*}{ MET. WEEK } & \multirow[t]{2}{*}{ PDI } & \multicolumn{2}{|c|}{ Temperature $\left({ }^{\circ} \mathrm{C}\right)$} & \multirow{2}{*}{$\begin{array}{l}\text { Rain } \\
\text { fall } \\
\text { Daily } \\
(\mathbf{m m})\end{array}$} & \multicolumn{2}{|c|}{$\begin{array}{c}\text { Relative } \\
\text { Humidity \% }\end{array}$} & \multirow{2}{*}{$\begin{array}{l}\text { Wind } \\
\text { velocity } \\
\mathbf{k m} / \mathbf{h r}\end{array}$} & \multirow{2}{*}{$\begin{array}{l}\text { BSH } \\
\text { hrs }\end{array}$} & \multirow{2}{*}{$\begin{array}{l}\text { Evapo } \\
(\mathbf{m m})\end{array}$} \\
\hline & & & Max & Min & & $7 \mathrm{hr}$ & $14 \mathrm{hr}$ & & & \\
\hline 6 & 08.02 .2017 & 0 & 32.3 & 16.7 & 0.0 & 94.1 & 37.4 & 2.1 & 7.5 & 3.7 \\
\hline 7 & 15.02 .2017 & 0.48 & 33.6 & 18.4 & 0.0 & 93.7 & 35.4 & 2.2 & 7.9 & 3.7 \\
\hline 8 & 22.02 .2017 & 0.80 & 34.7 & 20.2 & 0.0 & 93.4 & 36.4 & 4.0 & 8.5 & 3.8 \\
\hline 9 & 01.03 .2017 & 0.80 & 34.8 & 21.5 & 0.0 & 93.6 & 42.7 & 3.9 & 7.5 & 3.8 \\
\hline 10 & 08.03 .2017 & 1.08 & 35.9 & 22.5 & 16.8 & 91.9 & 39.4 & 4.8 & 7.1 & 4.6 \\
\hline 11 & 15.03.2017 & 1.08 & 31.9 & 21.5 & 28.6 & 93.9 & 49.0 & 4.3 & 5.6 & 4.6 \\
\hline 12 & 22.03 .2017 & 1.09 & 34.1 & 21.9 & 0.0 & 89.7 & 39.9 & 4.0 & 7.5 & 5.1 \\
\hline 13 & 29.03.2017 & 1.22 & 36.5 & 24.8 & 0.0 & 88.7 & 38.7 & 7.4 & 8.0 & 5.6 \\
\hline 14 & 05.04 .2017 & 1.23 & 35.8 & 25.7 & 0.0 & 86.3 & 44.3 & 11.0 & 7.5 & 6.1 \\
\hline 15 & 12.04 .2017 & 1.31 & 36.7 & 26.3 & 0.0 & 88.4 & 48.3 & 8.6 & 5.9 & 7.1 \\
\hline 16 & 19.04.2017 & 1.32 & 37.0 & 25.2 & 29.2 & 87.4 & 50.3 & 7.9 & 8.7 & 7.4 \\
\hline
\end{tabular}


Table.2 Simple correlation matrix between Blast and weather parameters for Khandagiri variety during rabi 2017

\begin{tabular}{|c|c|c|c|c|c|c|c|c|c|}
\hline Variables & BLAST & $\operatorname{Tmax}$ & Tmin & Rainfall & RHI & RHII & Wind vel. & BSH & Evapo \\
\hline BLAST & 1 & & & & & & & & \\
\hline $\operatorname{Tmax}$ & $0.693^{*}$ & 1 & & & & & & & \\
\hline Tmin & $0.931^{* *}$ & $0.809^{* *}$ & 1.000 & & & & & & \\
\hline Rainfall & 0.349 & -0.021 & 0.193 & 1.000 & & & & & \\
\hline RHI & $-0.744^{* *}$ & $-0.761^{* *}$ & $-0.873^{* *}$ & -0.026 & 1.000 & & & & \\
\hline RHII & $0.631^{*}$ & 0.270 & $0.655^{*}$ & $0.628^{*}$ & -0.463 & 1.000 & & & \\
\hline windvel. & $0.772^{* *}$ & $0.740^{* *}$ & $0.923^{* *}$ & 0.077 & $-0.910^{* *}$ & 0.576 & 1.000 & & \\
\hline BSH & -0.169 & 0.295 & -0.141 & -0.172 & -0.123 & -0.436 & -0.057 & 1.000 & \\
\hline Evapo & $0.767^{* *}$ & $0.721^{*}$ & $0.879^{* *}$ & 0.288 & $-0.896^{* *}$ & $0.724^{*}$ & $0.848^{*}$ & -0.070 & 1.000 \\
\hline
\end{tabular}

Table.3 Multiple Regression Analysis of influence of weather parameters on blast severity for Khandagiri variety during rabi 2017

\begin{tabular}{|c|c|c|c|c|c|c|}
\hline $\begin{array}{c}\text { Weather } \\
\text { Parameters }\end{array}$ & $\begin{array}{c}\text { Regression Coefficient } \\
\text { (b) }\end{array}$ & $\begin{array}{l}\text { Standard } \\
\text { Error }\end{array}$ & t Calculated & P - Value & $\begin{array}{l}\text { Intercept } \\
\text { (a) }\end{array}$ & $\mathbf{R}^{2}$ \\
\hline $\mathrm{X}_{1}-\mathrm{Tmax}$ & -0.119 & 0.110 & -1.081 & 0.393 & \multirow[t]{8}{*}{-2.683} & \multirow[t]{8}{*}{0.97} \\
\hline$X_{2}-T$ min & 0.283 & 0.093 & 3.034 & 0.094 & & \\
\hline $\mathrm{X}_{3}$ - Rainfall & 0.007 & 0.006 & 1.054 & 0.403 & & \\
\hline $\mathrm{X}_{4}-\mathrm{RHI}$ & 0.026 & 0.099 & 0.264 & 0.816 & & \\
\hline $\mathrm{X}_{5}-\mathrm{RHII}$ & -0.027 & 0.032 & -0.850 & 0.485 & & \\
\hline $\mathrm{X}_{6}$-Windvel. & -0.074 & 0.059 & -1.252 & 0.337 & & \\
\hline $\mathrm{X}_{7}-\mathrm{BSH}$ & 0.069 & 0.107 & 0.647 & 0.584 & & \\
\hline $\mathrm{X}_{8}$ - Evapo & 0.022 & 0.191 & 0.114 & 0.920 & & \\
\hline Equation & \multicolumn{6}{|c|}{$\begin{array}{l}Y=-2.683-0.119 \mathbf{X}_{\mathbf{1}}+0.283 \mathbf{X}_{\mathbf{2}}+0.007 \mathbf{X}_{\mathbf{3}}+0.026 \mathbf{X}_{\mathbf{4}}-0.027 \mathbf{X}_{\mathbf{5}}-0.074 \mathbf{X}_{\mathbf{6}}+0.069 \mathbf{X}_{7}+ \\
0.022 \mathbf{X}_{\mathbf{8}}\end{array}$} \\
\hline
\end{tabular}

Table.4 Influence of weather parameters on Blast disease of Lalat variety during rabi, 2017

\begin{tabular}{|c|c|c|c|c|c|c|c|c|c|c|}
\hline \multirow[t]{2}{*}{$\begin{array}{l}\text { WEEK } \\
\text { NO. }\end{array}$} & \multirow[t]{2}{*}{ MET. WEEK } & \multirow[t]{2}{*}{ PDI } & \multicolumn{2}{|c|}{$\begin{array}{c}\text { Temperature deg } \\
\text { C }\end{array}$} & \multirow{2}{*}{$\begin{array}{l}\text { Rainfall } \\
\text { Daily } \\
\text { (mm) }\end{array}$} & \multicolumn{2}{|c|}{$\begin{array}{c}\text { Relative } \\
\text { Humidity \% }\end{array}$} & \multirow{2}{*}{$\begin{array}{l}\text { Windvel. } \\
\text { km/hr }\end{array}$} & \multirow{2}{*}{$\begin{array}{l}\text { BSH } \\
\text { hrs }\end{array}$} & \multirow{2}{*}{$\begin{array}{l}\text { Evapo } \\
(\mathbf{m m})\end{array}$} \\
\hline & & & $\operatorname{Max}$ & Min & & $7 \mathrm{hr}$ & $14 \mathrm{hr}$ & & & \\
\hline 6 & 08.02 .2017 & 0 & 32.3 & 16.7 & 0.0 & 94.1 & 37.4 & 2.1 & 7.5 & 3.7 \\
\hline 7 & 15.02 .2017 & 1.52 & 33.6 & 18.4 & 0.0 & 93.7 & 35.4 & 2.2 & 7.9 & 3.7 \\
\hline 8 & 22.02.2017 & 1.63 & 34.7 & 20.2 & 0.0 & 93.4 & 36.4 & 4.0 & 8.5 & 3.8 \\
\hline 9 & 01.03 .2017 & 1.63 & 34.8 & 21.5 & 0.0 & 93.6 & 42.7 & 3.9 & 7.5 & 3.8 \\
\hline 10 & 08.03 .2017 & 1.71 & 35.9 & 22.5 & 16.8 & 91.9 & 39.4 & 4.8 & 7.1 & 4.6 \\
\hline 11 & 15.03 .2017 & 1.71 & 31.9 & 21.5 & 28.6 & 93.9 & 49.0 & 4.3 & 5.6 & 4.6 \\
\hline 12 & 22.03.2017 & 1.81 & 34.1 & 21.9 & 0.0 & 89.7 & 39.9 & 4.0 & 7.5 & 5.1 \\
\hline 13 & 29.03.2017 & 1.97 & 36.5 & 24.8 & 0.0 & 88.7 & 38.7 & 7.4 & 8.0 & 5.6 \\
\hline 14 & 05.04 .2017 & 1.97 & 35.8 & 25.7 & 0.0 & 86.3 & 44.3 & 11.0 & 7.5 & 6.1 \\
\hline 15 & 12.04 .2017 & 2.00 & 36.7 & 26.3 & 0.0 & 88.4 & 48.3 & 8.6 & 5.9 & 7.1 \\
\hline 16 & 19.04.2017 & 2.17 & 37.0 & 25.2 & 29.2 & 87.4 & 50.3 & 7.9 & 8.7 & 7.4 \\
\hline 17 & 26.04.2017 & 2.17 & 36.9 & 26.7 & 0.0 & 88.0 & 55.1 & 11.1 & 7.7 & 7.8 \\
\hline
\end{tabular}


Table.5 Simple correlation matrix between Blast and weather parameters for Lalat variety during rabi 2017

\begin{tabular}{|c|c|c|c|c|c|c|c|c|c|}
\hline Variables & BLAST & Tmax & Tmin & Rainfall & RHI & RHII & Windvel. & BSH & Evapo \\
\hline BLAST & 1 & & & & & & & & \\
\hline Tmax & $0.698^{*}$ & 1 & & & & & & & \\
\hline Tmin & $0.821^{* *}$ & $0.832^{* *}$ & 1.000 & & & & & & \\
\hline Rainfall & 0.202 & -0.075 & 0.107 & 1.000 & & & & & \\
\hline RHI & $-0.649^{*}$ & $-0.784^{* *}$ & $-0.882^{* *}$ & 0.025 & 1.000 & & & & \\
\hline RHII & 0.525 & 0.403 & $0.720^{* *}$ & 0.394 & -0.531 & 1.000 & & & \\
\hline windvel. & $0.664^{*}$ & $0.769^{* *}$ & $0.931^{* *}$ & -0.022 & $-0.897^{* *}$ & $0.705^{* *}$ & 1.000 & & \\
\hline BSH & 0.021 & 0.305 & -0.095 & -0.183 & -0.142 & -0.296 & -0.005 & 1.000 & \\
\hline Evapo & $0.641^{*}$ & $0.753^{* *}$ & $0.896^{* *}$ & 0.153 & $-0.884^{* *}$ & $0.808^{* *}$ & $0.889^{* *}$ & -0.015 & 1.000 \\
\hline
\end{tabular}

Table.6 Multiple regression analysis of influence of weather parameters on blast severity for Lalat variety during rabi 2017

\begin{tabular}{|c|c|c|c|c|c|c|}
\hline $\begin{array}{l}\text { Weather } \\
\text { Parameters }\end{array}$ & $\begin{array}{l}\text { Regression Coefficient } \\
\text { (b) }\end{array}$ & Standard Error & t Calculated & P - Value & $\begin{array}{l}\text { Intercept } \\
\text { (a) }\end{array}$ & $\mathbf{R}^{2}$ \\
\hline $\mathrm{X}_{1}-\mathrm{T} \max$ & -0.226 & 0.301 & -0.748 & 0.509 & \multirow[t]{8}{*}{-14.537} & \multirow[t]{8}{*}{0.84} \\
\hline $\mathrm{X}_{2^{-}}$Tmin & 0.498 & 0.260 & 1.914 & 0.152 & & \\
\hline $\mathbf{X}_{3^{-}}$Rainfall & 0.002 & 0.015 & 0.107 & 0.922 & & \\
\hline $\mathrm{X}_{4}-\mathrm{RHI}$ & 0.137 & 0.240 & 0.569 & 0.609 & & \\
\hline $\mathrm{X}_{5^{-}}$RHII & -0.034 & 0.089 & -0.386 & 0.725 & & \\
\hline $\mathrm{X}_{6}$-Windvel. & -0.118 & 0.156 & -0.760 & 0.502 & & \\
\hline $\mathrm{X}_{7}-\mathrm{BSH}$ & 0.305 & 0.265 & 1.151 & 0.333 & & \\
\hline $\mathrm{X}_{8}$ - Evapo & 0.071 & 0.495 & 0.143 & 0.895 & & \\
\hline Equation & $\begin{array}{l}Y=-14.537-0.226 \mathbf{X}_{1}+0 \\
\mathbf{X}_{\mathbf{8}}\end{array}$ & $8 \mathbf{X}_{2}+0.002 \mathbf{X}_{3}$ & $37 \mathbf{X}_{\mathbf{4}}-0$ & $\mathbf{x}_{5}-0.11$ & 0.305 & .071 \\
\hline
\end{tabular}

Correlation between the disease incidence and the weather parameters

The incidence of blast disease was correlated with the weather parameters and is presented in Table 2 and 5.

\section{Correlation within the variety Khandagiri}

The incidence of blast disease in variety Khandagiri was significant and high positively correlated with Minimum Temperature $(\mathrm{r}=0.931)$, Wind velocity $(\mathrm{r}=$ 0.772), Evaporation ( $\mathrm{r}=0.767)$ and high negatively correlated with Maximum Relative humidity $(r=0.744)$. The blast disease incidence was positively correlated with
Maximum Temperature ( $\mathrm{r}=0.693)$, Minimum Relative humidity $(\mathrm{r}=0.631)$ and there is no significant effect of both Rainfall $(r=0.349)$, $\mathrm{BSH}(\mathrm{r}=0.169)$.

\section{Correlation within the variety Lalat}

The incidence of blast disease in variety Lalat was significant and high positively correlated with Minimum Temperature $(r=0.821)$.

The blast disease incidence was positively correlated with Maximum Temperature ( $\mathrm{r}=$ $0.698)$, Wind velocity ( $r=0.664)$, Evaporation $(\mathrm{r}=0.641)$ and negatively correlated with Maximum Relative humidity ( $r=0.649)$. Rainfall ( $r=0.202)$, Minimum Relative 
humidity ( $\mathrm{r}=0.525)$ and $\mathrm{BSH}(0.021)$ have no effect on the disease incidence.

\section{Multiple regression analysis}

To handle eight independent weather variables and to identify critical and much contributing weather variable (s) separately towards the dependent variables i.e., blast disease (Table 3 and 6). Multiple regression analysis was performed. In variety Khandagiri, the multiple regression for blast disease severity revealed that $\mathrm{R}^{2}$ is $97 \%$ and the best fitted multiple regression equation is,

$\mathrm{Y}=-2.683-0.119 \mathrm{X}_{1}+0.283 \mathrm{X}_{2}+0.007 \mathrm{X}_{3}+$ $0.026 \mathrm{X}_{4}-0.027 \mathrm{X}_{5}-0.074 \mathrm{X}_{6}+0.069 \mathrm{X}_{7}+$ $0.022 \mathrm{X}_{8}$

And in variety Lalat, the multiple regression for blast disease severity revealed that $\mathrm{R}^{2}$ is $84 \%$ and the best fitted multiple regression equation is,

$\mathrm{Y}=-14.537-0.226 \mathrm{X}_{1}+0.498 \mathrm{X}_{2}+0.002 \mathrm{X}_{3}$ $+0.137 X_{4}-0.034 X_{5}-0.118 X_{6}+0.305$ $\mathrm{X}_{7}+0.071 \mathrm{X}_{8}$

In rabi season among the two varieties Khandagiri and Lalat varieties, Lalat variety showed the higher blast incidence $(2.17 \%)$ and Khandagiri variety was showed lowest blast incidence $(1.32 \%)$. The incidence of blast disease in variety Khandagiri was significant and high positively correlated with Minimum Temperature $(r=0.931)$, Wind velocity $(r=0.772)$, Evaporation $(r=0.767)$ and high negatively correlated with Maximum Relative humidity $(\mathrm{r}=0.744)$. The blast disease incidence was positively correlated with Maximum Temperature $(r=0.693)$, Minimum Relative humidity $(r=0.631)$ and there is no significant of both Rainfall ( $\mathrm{r}=$ $0.349)$, BSH $(r=0.169)$. The incidence of blast disease in variety Lalat was significant and high positively correlated with Minimum
Temperature $(\mathrm{r}=0.821)$. The blast disease incidence was positively correlated with Maximum Temperature $(r=0.698)$, Wind velocity $(r=0.664)$, Evaporation $(r=0.641)$ and negatively correlated with Maximum Relative humidity ( $\mathrm{r}=0.649)$. Rainfall $(\mathrm{r}=$ 0.202), Minimum Relative humidity ( $\mathrm{r}=$ $0.525)$ and BSH (0.021) have no effect on the disease incidence. Weather parameters played a major role in disease incidence in rabi season. In east \& south eastern coastal plain of Odisha location among the two varieties Lalat variety is very susceptible than Khandagiri.

\section{References}

Bhat, M.M. and Rajasab, A.H. 1988 Airspora of a commercial location at Gulbarga, Karnataka, India- Indian J Aerobiology

Castejon-munoz, 2008. The effect of temperature and relative humidity on the air-borne concentration of Pyricularia oryzae spores and the development of rice blast in southern Spain. Spanish Journal of Agricultural Research 6(1): 61-69.

Chakrabarti, N.K. and Padmanabhan, S.Y. 1968 - Prat: 55th Indian Sci. Cong:-. Part Ill (Absn-.)

Chaudhary RG and Vishwadhar. 1988. Epidemiology of rice blast and effect of date of sowing under up land conditions of Arunachal Pradesh, Indian Phytopathology. 41:552-557.

Directorate of Economics \& Statistics, DAC \&FW, 2015-16.

Food and Agriculture Organization, FAO, 1999

Gomez, K.A. and A.A. Gomez, (1984). Statistical procedures for agricultural research (2 ed.). John wiley and sons, NewYork, 680p.

Gouramanis GD. 1994. The present status of rice diseases and their control in 
Northern Grece, Cahiers Options Mediterraneennes, 15 (4):97-100.

Gouramanis GD. 1994. The present status of rice diseases and their control in Northern Grece, Cahiers Options Mediterraneennes, 15 (4):97-100.

Gowda S and Gowda PKT. 1985. Epidemiology of blast disease of rice, Indian Phytopathology, 38:143-145.

Kapoor AS and Singh BH. 1977. Influence of some environmental factors on spore germination and infection of rice by Pyricularia oryzae, Indian Phytopathology, 30:369-373.

Kato, H and Kozaka, T. 1947. Effect of temperature on lesion enlargement and sporulation of Pyricularia oryzae in rice leaves. Phytopathology. 64:828-830.

McKinney, H.H. (1923). A new system of grading plant diseases. Agric. Res., 26: 95-98.

Pal R, Mandal D and Naik BS. 2017. Effect of different meteorological parameters on the development and progression of rice leaf blast disease in western Odisha, $i$-scholar, 10 (1):52-57.

Panse V.G. and Sukhatme, P.V. (1984) Statistical methods for agricultural workers. Third Edition, Indian Council of Agricultural Research, New Delhi.

Rajput LS, Sharma T, Madhusudhan P and Sinha P. 2017. Effect of temperature on growth and sporulation of rice leaf blast pathogen Magnaporthe oryzae,

Ramakrishnan, K.V. 1948. Studies on morphology, physiology and parasitism of the genus Pyricularia in Madras. Proceedings of Indian Academy of Sciences Sec. B. 174-193.

Shafaullah, Khan MA, Khan NA and Mahmood Y. 2011. Effect of epidemiological factors on the incidence of paddy blast (Pyricularia oryzae) disease, Pakistan Journal of Phytopathology, 23(2):108-111.

Syakira N, Jack A and Chan CW. 2016. The effect of physical environmental factors of on the development of infield rice blast disease incidence, International Conference on Agricultural and Food Engineering, 23-25.

Tuite, J. (1969) Plant pathological methods: fungi and bacteria. Burgess Pub. Co., Minneapolis., USA, 239.

Uddin, N. and Chakraverty, R. 1996 Pathogenic and non-pathogenic mycoflora in the air and phylloplane of Triticum aestivum L. - AerobiologiaSpringer

Verma, K.S. and Khare, K. 1987 - Study of air spora around Jabalpur University Campus-J. Econ. Tax Bot

Verma, K.S. and Khare, K. 1988 Aeromycology at Jabalpur: A preliminary study- Indian J. Aerobiol.

\section{How to cite this article:}

Pradhan, J., A. Baliarsingh, G. Biswal, M.P. Das and Pasupalak, S. 2018. Effect of Weather Parameters on Infestation of Blast Disease (Pyricularia oryzae) in Rabi Season Rice (Oryza sativa L.) in East \& South Eastern Coastal Plain of Odisha. Int.J.Curr.Microbiol.App.Sci. 7(11): 893-900. doi: https://doi.org/10.20546/ijcmas.2018.711.106 